\title{
Synthesis and Degree of Branching of Epoxy-Terminated Hyperbranched Polysiloxysilane
}

\author{
By Kazutoshi YoKomaCHI, Makoto SEINO, Stephen J. GRUNZINGER, \\ Teruaki HAYAKAWA, and Masa-aki KAKIMOTO*
}

Hyperbranched polysiloxysilane (HBPS) with terminal vinyl groups P1 was synthesized by self-condensation reaction using platinum-catalyzed hydrosilylation of 1,1,3,5,5-pentamethyl-1,5-divinyltrisiloxane. A number-average molecular weight $\left(M_{\mathrm{n}}\right)$ was 5400 with a polydispersity index of 1.49 . End-functionalization of the terminal vinyl groups was carried out by epoxidation with 3-chloroperoxybenzoic acid to afford epoxy-terminated HBPS P2. The polymers obtained were characterized by IR, ${ }^{1} \mathrm{H},{ }^{13} \mathrm{C},{ }^{29} \mathrm{Si}$ NMR spectroscopy. The degree of branching of HBPS was estimated as 0.57 in comparison of ${ }^{29} \mathrm{Si}$ NMR spectra of $\mathbf{P} 2$ and model compounds. The glass transition temperatures $\left(T_{\mathrm{g}}\right)$ of $\mathbf{P 1}$ and $\mathbf{P} 2$ were observed at $-97^{\circ} \mathrm{C}$ and $-77^{\circ} \mathrm{C}$, respectively. The $10 \%$ weight loss temperatures $\left(T_{10}\right)$ of $\mathbf{P 1}$ and $\mathbf{P 2}$ were over $440{ }^{\circ} \mathrm{C}$ in nitrogen.

KEY WORDS: Hyperbranched Polymer / Polysiloxysilane / End-functionalization / Epoxidation / Degree of Branching /

Developing siloxane-based organic-inorganic hybrid polymers has attracted much attention in studies on interfaces of various organic/inorganic materials because of their unique properties such as adhesion, excellent thermal and oxidative stability, lubricity, high flexibility, and biocompatibility. 1,2 Although many and various types of the siloxane-based polymers have been developed, ${ }^{2-5}$ hyperbranched polysiloxysilanes (HBPS) are of particular recent interest. HBPS can be prepared by a facile and reliable one-pot synthetic method from hydrosilylation of $\mathrm{AB}_{\mathrm{x}}$ type siloxane-monomers having silicon hydride $(\mathrm{SiH})$ groups and terminal carbon-carbon double bonds, where $\mathrm{x}$ determines the ideal number of branches per repeating unit, to afford a large number of terminal functional groups of $\mathrm{SiH}$ or unsaturated bonds. ${ }^{6-10}$ Furthermore, the resulting terminal groups can be easily modified to various other functional groups that offer opportunities for tailoring the polymers to specific applications for which multiple functionalities may be advantageous. ${ }^{7-10}$

However, little attention has been given to study of the degree of branching for HBPS. ${ }^{9}$ The key properties of hyperbranched polymers such as viscosity and solubility are generally often determined by not only molecular weights, the kind of or the number of terminal functional groups, but also the degree of branching. ${ }^{11}$

Herein, in order to evaluate the modification potential of the terminal functional groups and the degree of branching of HBPS, we report the synthesis of the epoxy-terminated HBPS via the hydrosilylation of 1,1,3,5,5-pentamethyl-1,5divinyltrisiloxane as an $\mathrm{AB}_{2}$ type monomer and subsequent epoxidation of the resulting vinyl-terminated HBPS. The degree of branching for the epoxy-terminated HBPS was investigated by comparing to the ${ }^{29} \mathrm{Si} \mathrm{NMR}$ spectrum of model compounds.

\section{EXPERIMENTAL}

\section{Measurements}

NMR $\left({ }^{1} \mathrm{H}, 300 \mathrm{MHz} ;{ }^{13} \mathrm{C}, 75 \mathrm{MHz} ;{ }^{29} \mathrm{Si}, 59.4 \mathrm{MHz}\right)$ spectra were obtained in $\mathrm{CDCl}_{3}$ on a JEOL JNM-AL $300 \mathrm{NMR}$ spectrometer. Chemical shifts are reported in ppm, relative to $\mathrm{CHCl}_{3}\left(\delta 7.24,{ }^{1} \mathrm{H}\right), \mathrm{CDCl}_{3}\left(\delta 77.0,{ }^{13} \mathrm{C}\right)$, and tetramethylsilane $\left(\delta 0.0,{ }^{29} \mathrm{Si}\right.$ ). Infrared (IR) spectra were recorded using a JASCO FT/IR 460 plus spectrometer. Gel permeation chromatography (GPC) measurements coupled with multi-angle laser light scattering (MALLS) detector (Wyatt Technology miniDawn tristar) using tetrahydrofuran (THF) as an eluent, were carried out using a JASCO HBPX $880 \mathrm{Pu}$, two polystyrene-divinylbenzene columns (two Shodex GPC LF-804), and a Shodex RI-71 refractive index detector. The molecular weight characteristics of the polymers were calculated by polystyrene calibration curve constructed from 8 polystyrene standards. MALLS measurements were performed using ASTRA $^{\circledR} 4.90$ from Wyatt Technology, which acquired data from the 3 scattering angles detector (miniDAWN tirstar) and a refractive index detector. Differential scanning calorimetry (DSC) measurements were carried out using a Seiko DSC 6200 at a heating rate of $10{ }^{\circ} \mathrm{C} \mathrm{min}^{-1}$ in nitrogen. The glass transition temperature $\left(T_{\mathrm{g}}\right)$ was taken at the middle of the step transition in the second heating run. Thermogravimetric analysis (TGA) and differential thermal analysis (DTA) were carried out using a Seiko TG/DTA 6200 at a heating rate of $10^{\circ} \mathrm{C} \mathrm{min}^{-1}$ in nitrogen.

\section{Materials \\ Platinum(0)-1,3-divinyl-1,1,3,3-tetramethyldisiloxane com- plex $[\mathrm{Pt}(\mathrm{dvs})]$ solution in xylenes (Aldrich) was used as}


received. Aniline was dried over calcium hydride and distilled under reduced pressure. Triethylamine was dried over calcium hydride and distilled. Diethylether and toluene were dried and distilled over sodium metal and benzophenone ketyl under nitrogen. The other reagents and solvents were used as received. 1,1,3,5,5-Pentamethyl-1,5-divinyltrisiloxane (1). Diethylether $(700 \mathrm{~mL})$, aniline $(8.38 \mathrm{~g}, 90 \mathrm{mmol})$, and water $(1.48 \mathrm{~g}, 82$ mmol) were charged into a three-necked flask equipped with a dropping funnel and a condenser. A solution of vinyldimethylchlorosilane $(11.6 \mathrm{~mL}, 82 \mathrm{mmol})$ in diethylether $(50 \mathrm{~mL})$ was slowly added dropwise to the mixture at $0{ }^{\circ} \mathrm{C}$ with vigorous stirring. After the mixture was stirred at this temperature for $15 \mathrm{~min}$, the precipitate of aniline hydrochloride was filtered off. After drying the resulting solution over $\mathrm{MgSO}_{4}$, the solution was combined with triethylamine $(7.51 \mathrm{~g}, 74 \mathrm{mmol})$ in a threenecked flask equipped with a dropping funnel and a condenser. A solution of dichloromethylsilane $(3.5 \mathrm{~mL}, 34 \mathrm{mmol})$ in diethylether $(50 \mathrm{~mL})$ was slowly added dropwise to the solution at $0^{\circ} \mathrm{C}$ with vigorous stirring. The precipitate of triethylamine hydrochloride was filtered off and then the solvent was removed under reduced pressure to give a colorless liquid. Distillation of the residue under reduced pressure afforded $\mathbf{1}$ as a colorless liquid $(3.77 \mathrm{~g}, 45 \%)$. IR ( $\mathrm{KBr}, v)$ : 2961, 2152, 1408, 1257, 1059, 957, 910. ${ }^{1} \mathrm{H} \mathrm{NMR}\left(\mathrm{CDCl}_{3}, \delta\right): 0.11(\mathrm{~d}, 3 \mathrm{H}, J=$ $\left.1.4 \mathrm{~Hz}, \mathrm{SiCH}_{3}\right), 0.17$ (s, 12H, $\left.\mathrm{SiCH}_{3}\right), 4.65$ (q, $1 \mathrm{H}, J=1.4 \mathrm{~Hz}$, $\mathrm{SiH}), 5.73\left(\mathrm{q}, 1 \mathrm{H}, J=4.4 \mathrm{~Hz}, 19.4 \mathrm{~Hz}, \mathrm{SiCH}=\mathrm{CH}_{2}\right), 5.94(\mathrm{q}$, $\left.1 \mathrm{H}, J=4.4 \mathrm{~Hz}, 14.9 \mathrm{~Hz}, \mathrm{SiCH}=\mathrm{CH}_{2}\right), 6.11(\mathrm{q}, 1 \mathrm{H}, J=14.9$ $\left.\mathrm{Hz}, 19.4 \mathrm{~Hz}, \mathrm{SiCH}=\mathrm{CH}_{2}\right) .{ }^{13} \mathrm{C} \mathrm{NMR}\left(\mathrm{CDCl}_{3}, \delta\right): 0.1,1.5$, 132.0, 138.9. ${ }^{29} \mathrm{Si} \mathrm{NMR}\left(\mathrm{CDCl}_{3}, \delta\right):-35.4,-2.1$.

Vinyl-Terminated HBPS (P1). $\quad \mathrm{AB}_{2}$ type monomer 1 (18.49 g, $75 \mathrm{mmol})$ was charged into a two-necked flask. Pt(dvs) solution in xylenes $(0.75 \mathrm{~mL}, 0.075 \mathrm{mmol})$ was added at $0{ }^{\circ} \mathrm{C}$ with vigorous stirring. The system was then allowed to warm to room temperature and stirred for $15 \mathrm{~h}$. The polymer was dissolved in diethylether $(30 \mathrm{~mL})$ and precipitated into methanol $(300 \mathrm{~mL})$ three times. P1 was obtained as a colorless viscous liquid $(8.31 \mathrm{~g}, 47 \%)$. GPC based on polystyrene calibration: $M_{\mathrm{n}}=4140, M_{\mathrm{w}} / M_{\mathrm{n}}=1.48$. GPC-MALLS: $M_{\mathrm{n}}=$ 4810, $M_{\mathrm{w}} / M_{\mathrm{n}}=1.60$. IR $(\mathrm{KBr}, v): 2958,2910,2874,1596$, 1407, 1256, 1135, 1047, 955. ${ }^{1} \mathrm{H} \mathrm{NMR}\left(\mathrm{CDCl}_{3}, \delta\right):-0.07[\mathrm{br}$, $\left.\mathrm{SiCH}\left(\mathrm{CH}_{3}\right) \mathrm{Si}\right],-0.01-0.18\left(\mathrm{~m}, \mathrm{SiCH}_{3}\right), 0.37,0.43$ (br, $\mathrm{SiCH}_{2}-$ $\left.\mathrm{CH}_{2} \mathrm{Si}\right), 0.92-1.02\left[\mathrm{~m}, \mathrm{SiCH}\left(\mathrm{CH}_{3}\right) \mathrm{Si}\right], 5.71\left(\mathrm{~m}, \mathrm{SiCH}=\mathrm{CH}_{2}\right)$, $5.91\left(\mathrm{~m}, \mathrm{SiCH}=\mathrm{CH}_{2}\right), 6.13\left(\mathrm{~m}, \mathrm{SiCH}=\mathrm{CH}_{2}\right) .{ }^{13} \mathrm{C} \mathrm{NMR}$ $\left(\mathrm{CDCl}_{3}, \delta\right)$ : $-1.1,-0.2,0.2,0.6,1.6,8.1,8.9,9.6,11.8$, 131.7, 139.4. ${ }^{29} \mathrm{Si} \mathrm{NMR}\left(\mathrm{CDCl}_{3}, \delta\right):-22.1,-21.8,-21.1$, $-20.5,-19.9,-4.8,-4.6,-4.5,-3.3,7.0,7.4,7.6,7.9,8.1$.

Epoxy-Terminated HBPS (P2). P1 (1.23 g), toluene (10 mL), and 3-chloroperoxybenzoic acid $(1.73 \mathrm{~g}, 10 \mathrm{mmol})$ were charged into a two-necked flask. The mixture was stirred for $48 \mathrm{~h}$. Then the generated precipitate was filtered off. The residue was dissolved in hexane $(50 \mathrm{~mL})$, and extracted with $4 \times 200 \mathrm{~mL}$ of a saturated $\mathrm{NaHCO}_{3}$ solution. The organic phase was then dried over $\mathrm{MgSO}_{4}$. Removal of the solvent under high vacuum for $6 \mathrm{~h}$ afforded $\mathbf{P 2}(0.96 \mathrm{~g}, 73 \%)$ as a colorless viscous liquid. GPC based on polystyrene calibration: $M_{\mathrm{n}}=3950, M_{\mathrm{w}} / M_{\mathrm{n}}=$ 1.45. GPC-MALLS: $M_{\mathrm{n}}=4710, M_{\mathrm{w}} / M_{\mathrm{n}}=1.52$. IR $(\mathrm{KBr}, v)$ :
2957, 2912, 2874, 1407, 1319, 1256, 1231, 1136, 1047. ${ }^{1} \mathrm{H}$ NMR $\left(\mathrm{CDCl}_{3}, \delta\right):-0.09$ [br, $\left.\mathrm{SiCH}\left(\mathrm{CH}_{3}\right) \mathrm{Si}\right],-0.05-0.09$ $\left(\mathrm{m}, \mathrm{SiCH}_{3}\right), 0.40$ (br, $\mathrm{SiCH}_{2} \mathrm{CH}_{2} \mathrm{Si}$ ), 0.90-1.02 [m, SiCH$\left.\left(\mathrm{CH}_{3}\right) \mathrm{Si}\right], 2.15\left[\mathrm{~m}, \mathrm{SiCH}\left(\mathrm{OCH}_{2}\right)\right], 2.57$ [m, $\left.\mathrm{SiCH}\left(\mathrm{OCH}_{2}\right)\right], 2.86$ $\left[\mathrm{m}, \mathrm{SiCH}\left(\mathrm{OCH}_{2}\right)\right] .{ }^{13} \mathrm{C} \mathrm{NMR}\left(\mathrm{CDCl}_{3}, \delta\right):-1.8,-1.6,-1.4$, $-1.3,-1.1,-0.6,0.1,1.5,7.8,8.8,9.4,11.6,11.7,43.5,44.3$. ${ }^{29} \mathrm{Si} \mathrm{NMR}\left(\mathrm{CDCl}_{3}, \delta\right):-21.7,-21.2,-20.3,-19.8,-19.0$, $-18.5,1.4,1.9,7.8,8.5$.

Terminal Vinyl-Model Compound [2(T)], and Linear/Terminal Vinyl-Model Compound [3(L/T)]. $1(2.47 \mathrm{~g}, 10 \mathrm{mmol})$, vinyltrimethylsilane $(20.00 \mathrm{~g}, 200 \mathrm{mmol})$ and $\mathrm{Pt}(\mathrm{dvs})$ solution in xylenes $(0.1 \mathrm{~mL}, 0.01 \mathrm{mmol})$ were charged into a threenecked flask. The mixture was stirred for $15 \mathrm{~h}$. Removal of volatile materials under reduced pressure afforded the crude products. Preparative gel permeation chromatography of crude products with THF as an eluent gave 2 (T) $(0.24 \mathrm{~g}, 8 \%)$ and 3(L/T) $(0.23 \mathrm{~g}, 4 \%)$.

2(T): IR (KBr, v): 2957, 2909, 1596, 1407, 1256, 1136, 1050, 956. ${ }^{1} \mathrm{H}$ NMR $\left(\mathrm{CDCl}_{3}, \delta\right):-0.05\left(\mathrm{~s}, 9 \mathrm{H}, \mathrm{SiCH}_{3}\right), 0.00$ (s, 3H, $\left.\mathrm{SiCH}_{3}\right), 0.14$ (s, 12H, $\left.\mathrm{SiCH}_{3}\right), 0.36\left(\mathrm{~m}, 4 \mathrm{H}, \mathrm{SiCH}_{2} \mathrm{CH}_{2} \mathrm{Si}\right), 5.71$ (q, $\left.2 \mathrm{H}, J=4.2 \mathrm{~Hz}, 19.9 \mathrm{~Hz}, \quad \mathrm{SiCH}=\mathrm{CH}_{2}\right), 5.91(\mathrm{q}, 2 \mathrm{H}$, $\left.J=4.2 \mathrm{~Hz}, 14.6 \mathrm{~Hz}, \mathrm{SiCH}=\mathrm{CH}_{2}\right), 6.11(\mathrm{q}, 2 \mathrm{H}, J=14.6 \mathrm{~Hz}$, $\left.19.9 \mathrm{~Hz}, \mathrm{SiCH}=\mathrm{CH}_{2}\right) .{ }^{13} \mathrm{C} \mathrm{NMR}\left(\mathrm{CDCl}_{3}, \delta\right):-2.3,-1.2,0.3$, 7.8, 9.5, 131.6, 139.4. ${ }^{29} \mathrm{Si} \mathrm{NMR}\left(\mathrm{CDCl}_{3}, \delta\right):-19.8,-4.3,3.2$. 3(L/T): IR (KBr, v): 2957, 2873, 1596, 1407, 1256, 1135, 1047, 955. ${ }^{1} \mathrm{H} \mathrm{NMR}\left(\mathrm{CDCl}_{3}, \delta\right):-0.06-0.14 \quad[\mathrm{~m}$, $\mathrm{SiCH}\left(\mathrm{CH}_{3}\right) \mathrm{Si}, \mathrm{SiCH}_{3}$ ], 0.32-0.40 (m, $\left.\mathrm{SiCH}_{2} \mathrm{CH}_{2} \mathrm{Si}\right), 0.99$ [d, $J=7.5 \mathrm{~Hz} \mathrm{SiCH}(\mathrm{CH}) \mathrm{Si}], 5.70\left(\mathrm{~m}, \mathrm{SiCH}=\mathrm{CH}_{2}\right), 5.91(\mathrm{~m}$, $\left.\mathrm{SiCH}=\mathrm{CH}_{2}\right), 6.12\left(\mathrm{~m}, \mathrm{SiCH}=\mathrm{CH}_{2}\right),{ }^{13} \mathrm{C} \mathrm{NMR}\left(\mathrm{CDCl}_{3}, \delta\right)$ : $-2.3,-1.1,-0.5,0.1,0.3,1.5,7.9,9.6,11.8,131.6,139.5$.

${ }^{29} \mathrm{Si} \mathrm{NMR}\left(\mathrm{CDCl}_{3}, \delta\right):-21.0,-20.5,-19.9,-4.9,-4.5$, $-4.4,3.1,7.5,8.1$.

Dendritic Model Compound [4(D)]. 2(T) (0.14 g, $0.42 \mathrm{mmol})$, 1,1,1,3,5,5,5-heptamethyltrisiloxane $(0.93 \mathrm{~g}, 4.2 \mathrm{mmol})$, and $\mathrm{Pt}(\mathrm{dvs})$ solution in xylenes $(0.01 \mathrm{~mL}, 0.001 \mathrm{mmol})$ were charged into a two-necked flask. The mixture was stirred for $15 \mathrm{~h}$. Removal of volatile materials under reduced pressure afforded the crude products. Preparative gel permeation chromatography of crude products with THF as an eluent gave 4(D) (0.24 g, 74\%). IR (KBr, v): 2957, 2909, 1406, 1256, 1136. ${ }^{1} \mathrm{H}$ NMR $\left(\mathrm{CDCl}_{3}, \delta\right): 0.00-0.15\left(\mathrm{~m}, 66 \mathrm{H}, \mathrm{SiCH}_{3}\right), 0.38-0.50$ $\left(\mathrm{m}, 12 \mathrm{H}, \mathrm{SiCH}_{2} \mathrm{CH}_{2} \mathrm{Si}\right) .{ }^{13} \mathrm{C} \mathrm{NMR}\left(\mathrm{CDCl}_{3}, \delta\right):-2.2,-1.2$, $-0.5,1.9,8.0,8.9,9.5,9.6 .{ }^{29} \mathrm{Si} \mathrm{NMR}\left(\mathrm{CDCl}_{3}, \delta\right):-21.3$, $-20.8,3.1,6.8,7.9$.

Linear Vinyl-Model Compound [5(L)]. 2(T) (0.24 g, $0.70 \mathrm{mmol}), 1,1,1,3,5,5,5$-heptamethyltrisiloxane $(0.15 \mathrm{~g}, 0.70$ $\mathrm{mmol})$, diethylether $(1.0 \mathrm{~mL})$, and $\mathrm{Pt}(\mathrm{dvs})$ solution in xylenes $(0.01 \mathrm{~mL}, 0.001 \mathrm{mmol})$ were charged into a two-necked flask. The mixture was stirred for $15 \mathrm{~h}$. Removal of volatile materials under reduced pressure afforded the crude products. Preparative gel permeation chromatography of crude products with THF as an eluent gave $\mathbf{5}(\mathbf{L})(0.28 \mathrm{~g}, 21 \%)$. IR $(\mathrm{KBr}, v)$ : 2957, 2909, 1596, 1407, 1256, 1136, 1051, 956. ${ }^{1} \mathrm{H}$ NMR $\left(\mathrm{CDCl}_{3}, \delta\right)$ : $-0.06-0.29\left(\mathrm{~m}, 45 \mathrm{H}, \mathrm{SiCH}_{3}\right), 0.30-0.45(\mathrm{~m}, 8 \mathrm{H}$, $\mathrm{SiCH}_{2} \mathrm{CH}_{2} \mathrm{Si}$ ), $5.71\left(\mathrm{q}, 1 \mathrm{H}, J=4.3 \mathrm{~Hz}, 20.1 \mathrm{~Hz}, \mathrm{SiCH}=\mathrm{CH}_{2}\right.$ ), $5.91\left(\mathrm{q}, 1 \mathrm{H}, J=4.3 \mathrm{~Hz}, 14.6 \mathrm{~Hz}, \mathrm{SiCH}=\mathrm{CH}_{2}\right), 6.10(\mathrm{q}, 1 \mathrm{H}$, 
$\left.J=14.6 \mathrm{~Hz}, \quad 20.1 \mathrm{~Hz}, \quad \mathrm{SiCH}=\mathrm{CH}_{2}\right) .{ }^{13} \mathrm{C} \mathrm{NMR}\left(\mathrm{CDCl}_{3}, \delta\right)$ : $-2.2,-1.2,-0.5,0.3,1.9,7.9,8.9,9.4,9.5,131.6,139.5$. ${ }^{29} \mathrm{Si} \mathrm{NMR}\left(\mathrm{CDCl}_{3}, \delta\right)$ : $-20.6,-20.4,-4.4,3.2,7.0,8.2$.

Terminal Epoxy-Model Compound [6(T)]. 2(T) $(0.18 \mathrm{~g}$, $0.53 \mathrm{mmol})$, toluene $(2 \mathrm{~mL})$, and 3-chloroperoxybenzoic acid $(0.37 \mathrm{~g}, 2.1 \mathrm{mmol})$ were charged into a two-necked flask. The mixture was stirred for $24 \mathrm{~h}$. The solvent was removed under reduced pressure. The residue was dissolved in hexane $(50 \mathrm{~mL})$, and washed with $4 \times 100 \mathrm{~mL}$ of a saturated $\mathrm{NaHCO}_{3}$ solution. The organic phase was then dried over $\mathrm{MgSO}_{4}$. Removal of the solvent under reduced pressure afforded $\mathbf{6}(\mathbf{T})$ $(0.14 \mathrm{~g}, 68 \%)$ as a colorless liquid. IR (KBr, v): 2956, 2912, 1406, 1319, 1257, 1232, 1136, 1052, 947. ${ }^{1} \mathrm{H} \mathrm{NMR}\left(\mathrm{CDCl}_{3}\right.$, $\delta):-0.08$ (s, 9H, $\left.\mathrm{SiCH}_{3}\right), 0.02\left(\mathrm{~s}, 3 \mathrm{H}, \mathrm{SiCH}_{3}\right), 0.11(\mathrm{~s}, 12 \mathrm{H}$, $\mathrm{SiCH}_{3}$ ), 0.34 (br, 4H, $\mathrm{SiCH}_{2} \mathrm{CH}_{2} \mathrm{Si}$ ), 2.13 [q, $1 \mathrm{H}, J=4.1$ $\left.\mathrm{Hz}, 5.6 \mathrm{~Hz}, \mathrm{SiCH}\left(\mathrm{OCH}_{2}\right)\right], 2.55[\mathrm{q}, 1 \mathrm{H}, J=4.1 \mathrm{~Hz}, 5.9 \mathrm{~Hz}$, $\left.\mathrm{SiCH}\left(\mathrm{OCH}_{2}\right)\right], 2.84\left[\mathrm{t}, 1 \mathrm{H}, J=5.6 \mathrm{~Hz}, 5.9 \mathrm{~Hz}, \mathrm{SiCH}\left(\mathrm{CH}_{2}\right)\right]$. ${ }^{13} \mathrm{C} \mathrm{NMR}\left(\mathrm{CDCl}_{3}, \delta\right):-2.4,-2.2,-1.8,-1.4,7.7,9.2,43.4$, 44.3. ${ }^{29} \mathrm{Si} \mathrm{NMR}\left(\mathrm{CDCl}_{3}, \delta\right):-18.3,1.8,3.3$.

Linear/Terminal Epoxy-Model Compound [7(L/T)]. 3(L/T) $(0.23 \mathrm{~g}, 0.38 \mathrm{mmol})$, toluene $(2 \mathrm{~mL})$, and 3-chloroperoxybenzoic acid $(0.39 \mathrm{~g}, 2.3 \mathrm{mmol})$ were charged into a two-necked flask. The mixture was stirred for $24 \mathrm{~h}$. The solvent was removed under reduced pressure. The residue was dissolved in hexane $(50 \mathrm{~mL})$, and washed with $4 \times 100 \mathrm{~mL}$ of a saturated $\mathrm{NaHCO}_{3}$ solution. The organic phase was then dried over $\mathrm{MgSO}_{4}$. Removal of the solvent under reduced pressure afforded 7(L/T) $(0.15 \mathrm{~g}, 62 \%)$ as a colorless liquid. IR (KBr, v): 2957, 2912, 1407, 1319, 1257, 1232, 1135, 1050, 947. ${ }^{1} \mathrm{H}$ NMR $\left(\mathrm{CDCl}_{3}, \delta\right)$ : -0.09-0.11 [m, $\left.\mathrm{SiCH}\left(\mathrm{CH}_{3}\right) \mathrm{Si}, \mathrm{SiCH}_{3}\right], 0.29-0.37$ (m, $\left.\mathrm{SiCH}_{2} \mathrm{CH}_{2} \mathrm{Si}\right), 0.97-1.01\left[\mathrm{~m}, \mathrm{SiCH}_{3}(\mathrm{CH}) \mathrm{Si}\right], 2.12[\mathrm{~m}$, $\left.\mathrm{SiCH}\left(\mathrm{OCH}_{2}\right)\right], 2.54\left[\mathrm{~m}, \mathrm{SiCH}\left(\mathrm{OCH}_{2}\right)\right], 2.84\left[\mathrm{~m}, \mathrm{SiCH}\left(\mathrm{OCH}_{2}\right)\right]$. ${ }^{13} \mathrm{C} \mathrm{NMR}\left(\mathrm{CDCl}_{3}, \delta\right):-2.4,-1.9,-1.8,-1.7,-1.3,-0.6,0.1$, 1.3, 7.7, 7.8, 9.4, 11.5, 43.5, 44.3. ${ }^{29} \mathrm{Si} \mathrm{NMR}\left(\mathrm{CDCl}_{3}, \delta\right):-20.1$, $-19.8,-19.1,-18.5,1.0,1.2,1.8,3.1,7.5,8.3$.

Linear Epoxy-Model Compound [8(L)]. $\quad$ 5(L) (0.06 g, 0.38 $\mathrm{mmol})$, toluene $(0.5 \mathrm{~mL})$, and 3-chloroperoxybenzoic acid $(0.038 \mathrm{~g}, 0.22 \mathrm{mmol})$ were charged into a two-necked flask. The mixture was stirred for $24 \mathrm{~h}$. The solvent was removed under reduced pressure. The residue was dissolved in hexane $(50 \mathrm{~mL})$, and washed with $4 \times 100 \mathrm{~mL}$ of a saturated $\mathrm{NaHCO}_{3}$ water solution. The organic phase was then dried over $\mathrm{MgSO}_{4}$. Removal of the solvent under reduced pressure afforded $8(\mathbf{L})$ $(0.04 \mathrm{~g}, 71 \%)$ as a colorless liquid. IR $(\mathrm{KBr}, v)$ : 2957, 2910, 1406, 1319, 1256, 1136, 1051, 947. ${ }^{1} \mathrm{H} \mathrm{NMR}\left(\mathrm{CDCl}_{3}, \delta\right)$ : -0.05-0.15 (m, 45H, $\left.\mathrm{SiCH}_{3}\right), 0.29-0.45\left(8 \mathrm{H}, \mathrm{SiCH}_{2} \mathrm{CH}_{2} \mathrm{Si}\right)$, $2.15\left[\mathrm{q}, 1 \mathrm{H}, J=4.1 \mathrm{~Hz}, 5.4 \mathrm{~Hz}, \operatorname{SiCH}\left(\mathrm{OCH}_{2}\right)\right], 2.52[\mathrm{q}, 1 \mathrm{H}$, $\left.J=4.1 \mathrm{~Hz}, 5.9 \mathrm{~Hz}, \mathrm{SiCH}\left(\mathrm{OCH}_{2}\right)\right], 2.81[\mathrm{t}, 1 \mathrm{H}, J=5.4 \mathrm{~Hz}$, $\left.5.9 \mathrm{~Hz}, \mathrm{SiCH}\left(\mathrm{OCH}_{2}\right)\right] .{ }^{13} \mathrm{C} \mathrm{NMR}\left(\mathrm{CDCl}_{3}, \delta\right):-2.3,-1.5$, $-1.2,-0.5,1.9,7.8,8.9,9.4,43.7,44.4 .{ }^{29} \mathrm{Si} \mathrm{NMR}\left(\mathrm{CDCl}_{3}\right.$, $\delta):-20.8,-19.7,1.3,3.2,7.0,8.6$.

\section{RESULTS AND DISCUSSION}

\section{Monomer Synthesis}

As the simplest $\mathrm{AB}_{x}$ type monomer for preparation of the
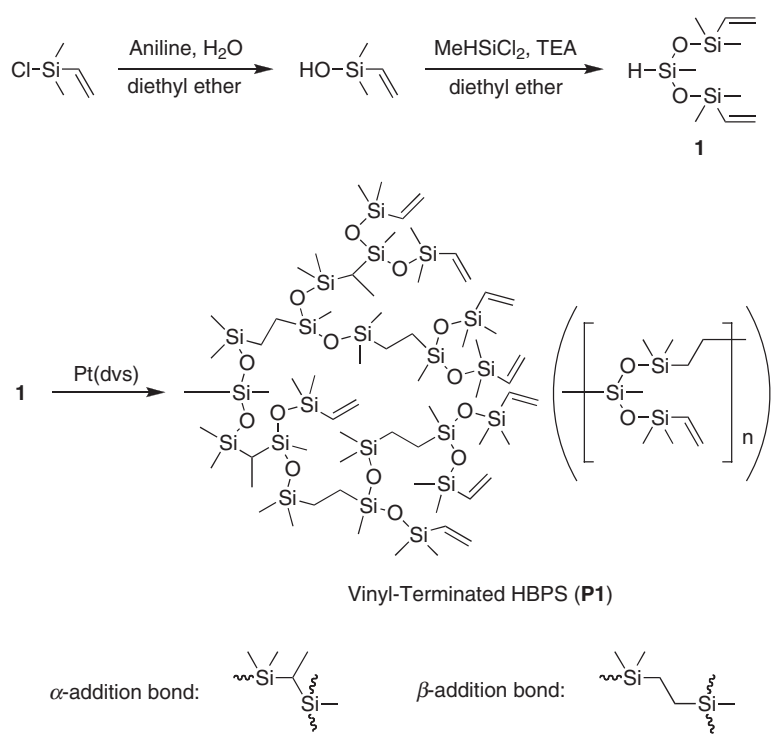

Scheme 1. Synthesis and polymerization of monomer 1.

vinyl-terminated HBPS P1, $\mathrm{AB}_{2}$ type monomer 1, 1,1,3,5,5pentamethyl-1,5-divinyltrisiloxane, was successfully prepared using the reactions outlined in Scheme 1. In the first step, hydrolysis of vinyldimethylchlorosilane was carried out to generate vinyldimethylsilanol. Condensation of the resulting vinyldimethylsilanol with dichloromethylsilane was performed in the presence of triethylamine to afford 1 in $45 \%$ yield. The structure of 1 was characterized by IR, ${ }^{1} \mathrm{H},{ }^{13} \mathrm{C}$, and ${ }^{29} \mathrm{Si} \mathrm{NMR}$ spectroscopies. In the IR spectrum, peaks due to the $\mathrm{Si}-\mathrm{O}$ stretching vibration were observed at $1059 \mathrm{~cm}^{-1}$. The ${ }^{1} \mathrm{H}$ NMR spectrum clearly showed signals at 4.65 and 5.7-6.1 ppm due to the silicon hydride ( $\mathrm{Si}-\mathrm{H}$ ) and vinyl groups, respectively. In the ${ }^{13} \mathrm{C}$ and ${ }^{29} \mathrm{Si}$ NMR spectra, four carbon signals and two silicon signals were observed. Analyses of these spectra confirmed that the desired monomer $\mathbf{1}$ was obtained without a side product.

\section{Polymerization of 1}

Hydrosilylation of $\mathbf{1}$ was carried out at room temperature for $15 \mathrm{~h}$ in the presence of $0.1 \mathrm{~mol} \%$ of $\mathrm{Pt}(\mathrm{dvs})$ in bulk to give P1 (Scheme 1). P1 was isolated in $47 \%$ yield after precipitating three times from a diluted diethylether solution into methanol. GPC indicated a symmetrical and unimodal peak with a number average molecular weight $\left(M_{\mathrm{n}}\right)$ of 4140 and a polydispersity index of 1.48 (versus polystyrene standard in THF). GPC-MALLS measurement indicated that the absolute value of the number average molecular weight is 4810 with a polydispersity index of 1.60 (Table I). Consistent with dendritic topology, the relative molecular weight value by calculated by GPC against polystyrene standards is a little smaller than the absolute value measured by GPC-MALLS measurement. The IR spectrum showed strong siloxane and vinyl bands at 1047 and $955 \mathrm{~cm}^{-1}$. No absorption corresponding to $\mathrm{Si}-\mathrm{H}$ around at $2150 \mathrm{~cm}^{-1}$ was observed. In the ${ }^{1} \mathrm{H}$ NMR spectrum, characteristic peaks were found at 0.97 and $0.40 \mathrm{ppm}$, which were assigned to methyl and methylene groups of the $\alpha$ - and $\beta$-addition products, respectively 
Table I. Molecular Weight of P1 and P2

\begin{tabular}{ccccc}
\hline \multirow{2}{*}{ Polymer } & \multicolumn{2}{c}{ GPC $^{a}$} & \multicolumn{2}{c}{ MALLS $^{b}$} \\
& $M_{\mathrm{n}}$ & $M_{\mathrm{w}} / M_{\mathrm{n}}$ & $M_{\mathrm{n}}$ & $M_{\mathrm{w}} / M_{\mathrm{n}}$ \\
\hline P1 & 4140 & 1.48 & 4810 & 1.60 \\
P2 & 3950 & 1.45 & 4710 & 1.52 \\
\hline
\end{tabular}

${ }^{a}$ Calculated by GPC against polystyrene standards. ${ }^{b}$ Calculated by GPC-MALLS

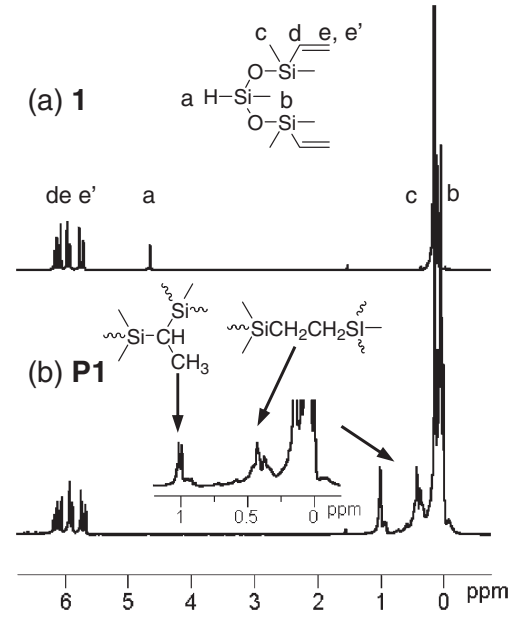

Figure 1. ${ }^{1} \mathrm{H}$ NMR spectra of $\mathbf{1}(\mathrm{a})$, and $\mathbf{P 1}(\mathrm{b})$.

(Figure 1). As shown in Figure 2, DEPT NMR spectrum revealed that the carbon signals of methyl and methine groups corresponding to the structure of $\alpha$-addition product were observed at 8.1 and $11.8 \mathrm{ppm}$, respectively. The methylene carbon signals due to the structure of $\beta$-addition product were found at 8.9 and $9.6 \mathrm{ppm}$. The ${ }^{29} \mathrm{Si} \mathrm{NMR}$ spectrum showed three multiplets at around $-21.1,-4.3$, and $7.6 \mathrm{ppm}$, which can be assigned to silicon atoms of $-\mathrm{O}-\mathrm{SiMe}_{2}-\mathrm{CH}_{2-}$, -O-SiMe $\mathrm{Me}_{2}$ $\mathrm{CH}=\mathrm{CH}_{2}$, $-\mathrm{CH}_{2}-\mathrm{SiMe}(\mathrm{O}-)_{2}$ in $\mathbf{P 1}$, respectively. Relative integration of the signals of $\alpha$ - and $\beta$-addition products in the ${ }^{1} \mathrm{H}$ NMR spectrum indicates that the $\beta$-addition is present in $64 \%$ of the linkages. This value is in good agreement with that of polycarbosiloxane prepared by hydrosilylation of dimethyl(dimethylvinylsiloxy)silane. ${ }^{12}$ The vinyl groups attached to a silicon atom with low steric hindrance can allow the formation of $\alpha$-addition product during the hydrosilylation reaction.

\section{Epoxidation of $\mathbf{P 1}$}

Epoxidation was used to evaluate the potential of the terminal vinyl group conversion. The epoxidation of the terminal vinyl groups of $\mathbf{P 1}$ was performed with 3-chloroperoxybenzoic acid at room temperature for $48 \mathrm{~h}$ and afforded the epoxy-terminated HBPS P2 (Scheme 2). The IR spectrum of $\mathbf{P 2}$ indicated characteristic epoxy groups at $1231,1319 \mathrm{~cm}^{-1}$. ${ }^{1} \mathrm{H}$ NMR analysis showed the complete disappearance of the terminal vinyl groups and the appearance of the methylene and methine protons corresponding to the epoxy groups at 2.15 , 2.57, and $2.86 \mathrm{ppm}$ (Figure 3 ). In the ${ }^{13} \mathrm{C} \mathrm{NMR}$ spectrum, characteristic signals were found at 43.5 and $44.3 \mathrm{ppm}$, which
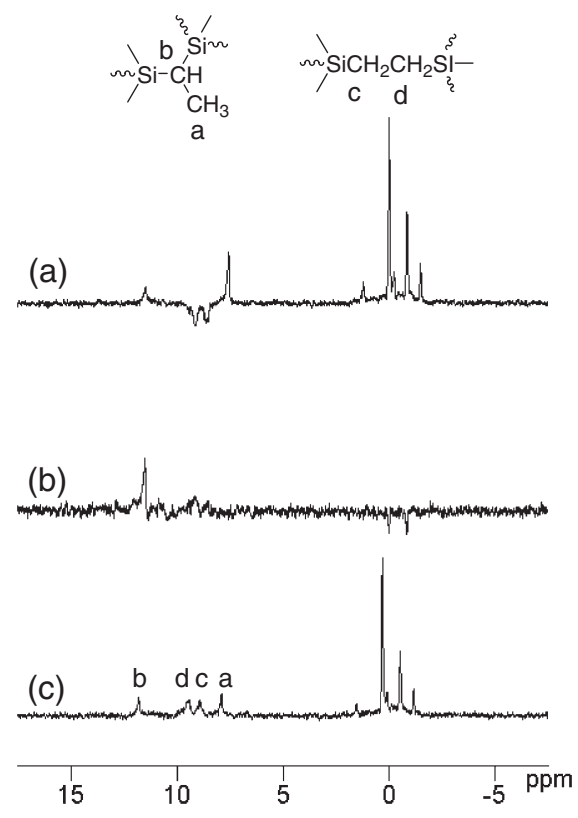

Figure 2. ${ }^{13} \mathrm{C}$ NMR spectra of P1: DEPT-135 (a), DEPT-90 (b), ${ }^{13} \mathrm{C}$ NMR (c).

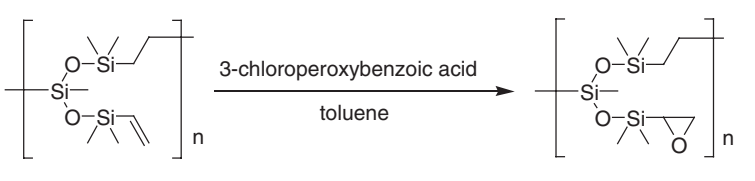

P1 Epoxy-Terminated HBPS (P2)

Scheme 2. Epoxidation of P1.

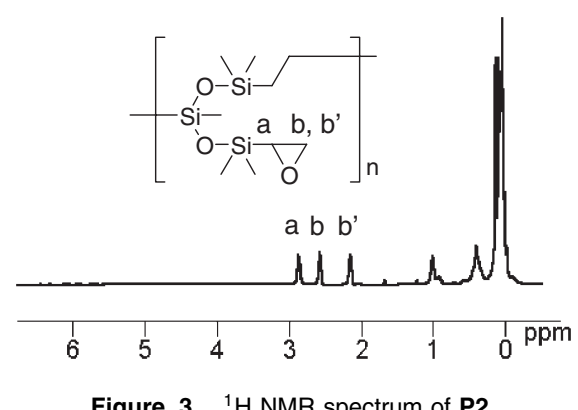

Figure 3. ${ }^{1} \mathrm{H}$ NMR spectrum of $\mathbf{P 2}$.

were assigned to the methylene and methine carbons of the epoxy group, respectively. All the signals were clearly assigned to $\mathbf{P 2}$ in the spectra, indicating quantitative conversion of the terminal vinyl groups. The absolute values of the number average molecular weight $\left(M_{\mathrm{n}}\right)$ and polydispersity were 4710 and 1.52 , respectively (Table I).

\section{Degree of Branching (DB)}

An important characteristic of hyperbranched polymers is degree of branching (DB) because properties such as solubility and viscosity strongly depend on the primary branching structure. ${ }^{11}$ We initially attempted to determine the DB of P1 from the ${ }^{29} \mathrm{Si}$ NMR signals, but it was difficult to estimate since the signals overlapped. Thus, the ${ }^{29} \mathrm{Si} \mathrm{NMR}$ signals from 

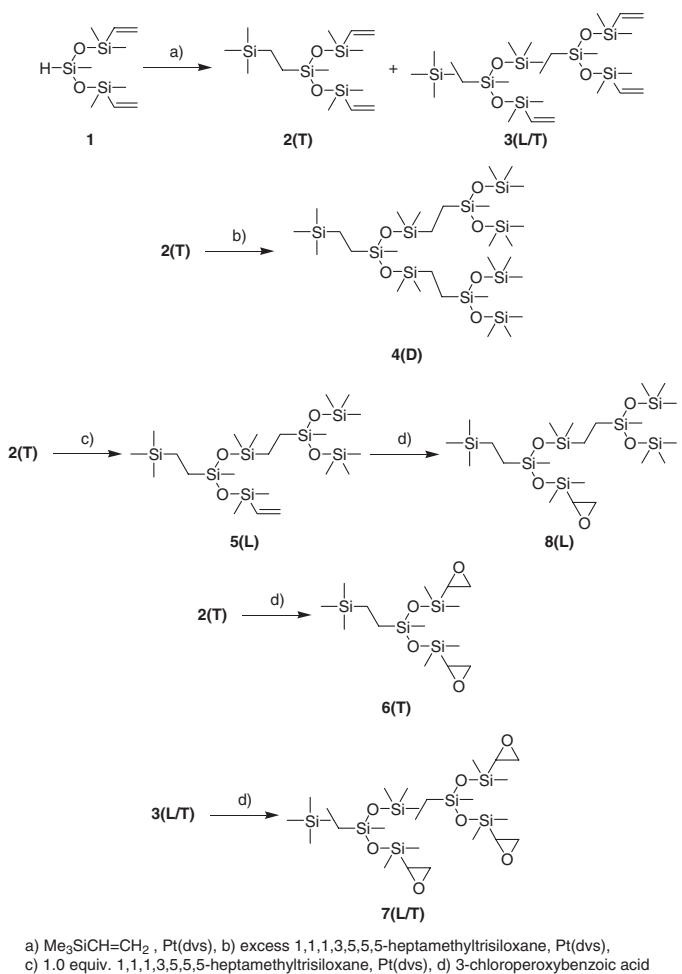

$8(\mathrm{~L})$

Scheme 3. Syntheses of the model compounds.

P2 were used for the DB estimation of HBPS in this study. In the ${ }^{29} \mathrm{Si}$ NMR spectrum from $\mathbf{P 2}$, the four distinct silicon signals and a broad signal attributed to $-\operatorname{SiMe}(\mathrm{O}-)_{2}$ at -18.5 , $-19.0,-19.8,-20.3$, and around $-21.5 \mathrm{ppm}$ were observed, respectively. These are due to $\alpha$ - and $\beta$-addition linear, terminal, and dendritic units.

In order to characterize these signals conclusively, several model compounds were prepared, which correspond to the linear $(\mathrm{L})$, terminal $(\mathrm{T})$, linear/terminal $(\mathrm{L} / \mathrm{T})$, and dendritic type (D) structures as shown in Scheme 3. The first synthetic step for the model compounds was hydrosilylation of monomer 1 performed with an excess amount of vinyltrimethylsilane to obtain compounds 2(T) and 3(L/T). Dendritic model compound 4(D) was synthesized by hydrosilylation of 2(T) and an excess amount of 1,1,1,3,5,5,5-heptamethyltrisiloxane. In order to obtain the linear model compound, hydrosilylation of 2 (T) was carried out with 1.0 equivalent of 1,1,1,3,5,5,5-heptamethytrisiloxane and an asymmetric compound with one terminal vinyl group 5(L) was obtained. Subsequently, epoxidation of the vinyl groups of $\mathbf{2}(\mathbf{T}), \mathbf{3}(\mathbf{L} / \mathbf{T})$, and $\mathbf{5}(\mathbf{L})$ was performed and afforded the terminal epoxy-model compound 6(T), the linear/terminal epoxy-model compound $7(\mathbf{L} / \mathbf{T})$ and the linear epoxy-model compound $\mathbf{8}(\mathbf{L})$, respectively. ${ }^{1} \mathrm{H}$ NMR spectra of $4(D), 6(T)$, and $\mathbf{8}(\mathrm{L})$ indicated only $\beta$-addition products. In contrast, $7(\mathbf{L} / \mathbf{T})$ consisted of a mixture of $\alpha$ - and $\beta$-addition products, as characteristic proton signals were observed at 0.99 and $0.33 \mathrm{ppm}$ in the ${ }^{1} \mathrm{H}$ NMR spectrum, which are consistent with methyl and methylene groups of $\alpha$ and $\beta$-addition products. (a)
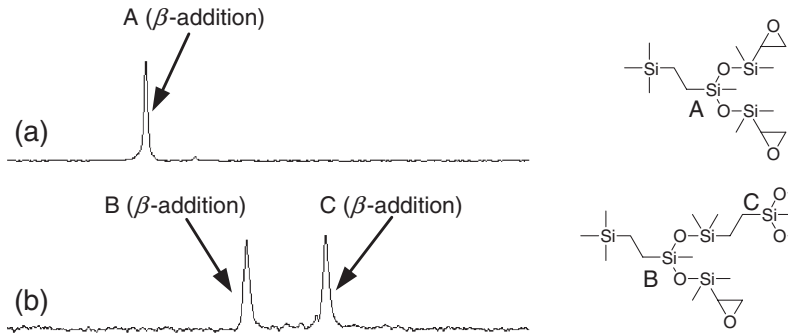

$\mathrm{E}(\alpha$-addition)
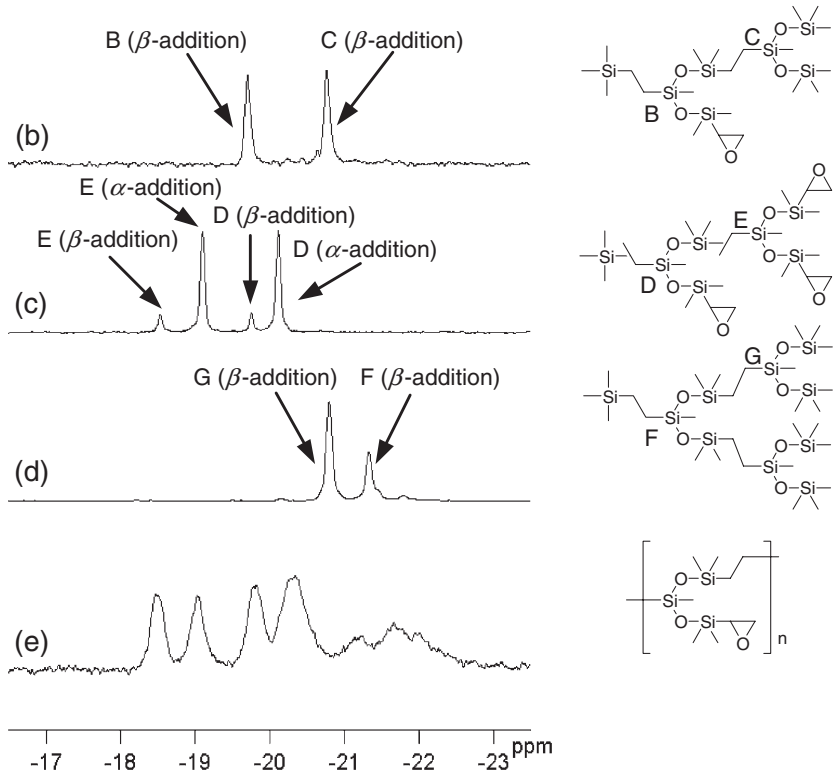

Figure 4. ${ }^{29} \mathrm{Si}$ NMR spectra of $6(\mathrm{~T})(\mathrm{a}), \mathbf{8 ( L )}(\mathrm{b}), \mathbf{7 ( L / T )}(\mathrm{c}), \mathbf{4 ( D )}(\mathrm{d})$, and P2 (e).

The expanded ${ }^{29} \mathrm{Si}$ NMR spectra of these model compounds and $\mathbf{P 2}$ are shown in Figure 4. The spectrum of $\mathbf{6}(\mathbf{T})$ had a single silicon signal corresponding to the terminal $\beta$-addition type $-\mathrm{SiMe}(\mathrm{O}-)_{2}$ at $-18.3 \mathrm{ppm}$. In the spectrum of $\mathbf{8}(\mathbf{L})$, two signals were observed at -19.7 and $-20.8 \mathrm{ppm}$ which were assigned to the linear and dendritic $\beta$-addition type $-\mathrm{SiMe}(\mathrm{O}-)_{2}$, respectively. In the case of $\mathbf{7}(\mathbf{L} / \mathbf{T})$, four silicon signals were observed at $-18.5,-19.1,-19.8$, and -20.1 . The signals at -18.5 and -19.1 were assigned to the terminal $\beta$ - and $\alpha$ addition type $-\mathrm{SiMe}(\mathrm{O}-)_{2}$, while the signals at -19.8 and -20.1 were due to the linear $\beta$ - and $\alpha$-addition type $-\operatorname{SiMe}(\mathrm{O}-)_{2}$, respectively. In the spectrum of $\mathbf{4}(\mathbf{D})$, the two signals of the $\beta$-addition type $-\mathrm{SiMe}(\mathrm{O}-)_{2}$ were observed at -20.8 and $-21.3 \mathrm{ppm}$. Based on the characterization of the model compounds, the silicon signals of $\mathbf{P 2}$ were assigned to the corresponding silicon atoms of the terminal $\beta$-addition unit $(-18.5 \mathrm{ppm})$, the terminal $\alpha$-addition unit $(-19.0 \mathrm{ppm})$, the linear $\beta$-addition unit $(-19.8 \mathrm{ppm})$, the linear $\alpha$-addition unit $(-20.3 \mathrm{ppm})$, and the dendritic unit (around $-21.5 \mathrm{ppm}$ ). Chemical shifts of the silicon signals in the $\mathbf{P 2}$ spectrum are good agreement with those of the model compounds.

Table II. Thermal properties of P1 and P2

\begin{tabular}{ccc}
\hline Polymer & $T_{\mathrm{g}}\left({ }^{\circ} \mathrm{C}\right)^{a}$ & $T_{10}\left({ }^{\circ} \mathrm{C}\right)^{b}$ \\
\hline P1 & -97 & 499 \\
P2 & -77 & 440
\end{tabular}

${ }^{a}$ Determined by DSC at heating rate of $10^{\circ} \mathrm{C} / \mathrm{min}$ on the second scan. ${ }^{b}$ Determined by TGA at heating rate of $10^{\circ} \mathrm{C} / \mathrm{min}$ in $\mathrm{N}_{2}$. 
Table III. Solubility of $\mathbf{P 1}$ and P2

\begin{tabular}{|c|c|c|c|c|c|c|c|c|c|c|}
\hline Polymer & Hexane & Toluene & $\mathrm{Et}_{2} \mathrm{O}$ & $\mathrm{CH}_{2} \mathrm{Cl}_{2}$ & $\mathrm{CHCl}_{3}$ & THF & Acetone & $\mathrm{MeOH}$ & DMF & DMAc \\
\hline P1 & ++ & ++ & ++ & ++ & ++ & ++ & - & - & - & - \\
\hline P2 & ++ & ++ & ++ & ++ & ++ & ++ & ++ & - & - & - \\
\hline
\end{tabular}

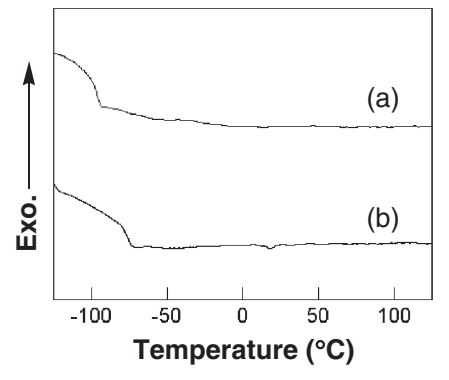

Figure 5. DSC curves of P1 (a), and P2 (b).

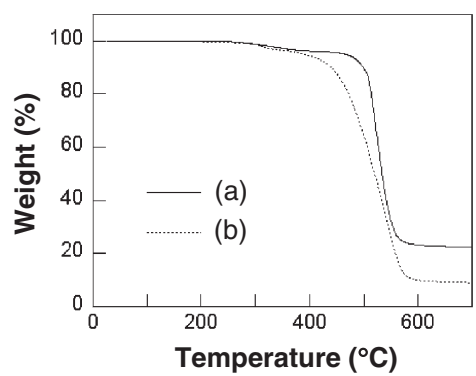

Figure 6. TGA curves of P1 (a), and P2 (b).

The degree of branching of $\mathbf{P 2}$ was determined following Frey's definition (1). ${ }^{13}$ By the integrated intensities of the signals, DB of $\mathbf{P 2}$ was calculated as 0.57 with the Frey's definition, which is a typical numerical value for hyperbranched polymers.

$$
\text { Degree of Branching }=\frac{2[\mathrm{D}]}{2[\mathrm{D}]+[\mathrm{L}]}
$$

\section{Thermal Properties and Solubility of P1 and P2}

The thermal behavior of $\mathbf{P 1}$ and $\mathbf{P 2}$ was examined by differential scanning calorimetry (DSC) and thermogravimetric analysis (TGA). In order to eliminate the effect of thermal history on sample transitions, the polymers were first heated to $100^{\circ} \mathrm{C}$ and held at this temperature for $1 \mathrm{~min}$, before cooling to $-130{ }^{\circ} \mathrm{C}$ at a rate of $10^{\circ} \mathrm{C} \min ^{-1}$. As shown in Figure 5 and Table II, P1 and $\mathbf{P 2}$ exhibit glass transition temperatures $\left(T_{\mathrm{g}}\right)$ below at $-70^{\circ} \mathrm{C}$ due to the highly flexible siloxane skeleton and the branching structure as the primary structure. From the TGA curves, $\mathbf{P 1}$ and $\mathbf{P 2}$ also have good thermal stability as the $10 \%$ weight loss temperatures $\left(T_{10}\right)$ are greater than $440{ }^{\circ} \mathrm{C}$ in nitrogen (Figure 6 and Table II). In the differential thermal analysis (DTA) curve of P2, an exothermic peak was observed at $315^{\circ} \mathrm{C}$. This is due to the crosslink reaction of the terminal epoxy groups.
P1 and P2 exhibit excellent solubility in hexane, diethyl ether, tetrahydrofuran, dichloromethane and chloroform while they are insoluble in alcohols and aprotic polar solvents such as $N, N$-dimethylformamide and $N, N$-dimethylacetoamide (Table III).

\section{CONCLUSION}

We have studied synthesis of HBPS with terminal vinyl and epoxy groups to evaluate the potential for terminal group modification and the degree of branching. The vinyl-terminated HBPS was readily prepared by hydrosilylation of 1,1,3,5,5pentamethyl-1,5-divinyltrisiloxane in the presence of $\mathrm{Pt}(\mathrm{dvs})$ in bulk. It was found that the resulting P1 consists of a mixture of $\alpha$ - and $\beta$-addition products and the ratio is 36:64. The epoxyterminated HBPS was obtained by epoxidation of the vinylterminated HBPS with 3-chloroperoxybenzoic acid. The degree of branching was estimated as 0.57 via a detail characterization of the ${ }^{29} \mathrm{Si}$ NMR spectra by model compounds. The large number of the vinyl and epoxy groups of HBPS can be modified to various functional groups that can offer unique organic and inorganic hybrid materials for surfaces and interfaces.

Received: September 4, 2007

Accepted: November 20, 2007

Published: January 17, 2008

\section{REFERENCES}

1. a) "Silicon-Based Polymer Science: a Comprehensive Resorce," J. M. Zeigler and F. W. G. Fearon, Ed., American Chemical Society, Washington D. C., 1989.

b) M. A. Brook, "Silicon in Organic Organometallic, and Polymer Chemistry," John Wily \& Sons, Inc., New York, 2000.

c) "Silicon in Polymer Synthesis," C. Burger, W. R. Helter, P. Kochs, F. Kreuzer, H. R. Kricheldorf, and R. Mülhaupt, Ed., Springer, Berlin, 1996.

2. Y. Abe and T. Gunji, Prog. Polym. Sci., 29, 149 (2004).

3. a) R. Bischoff and S. E. Cray, Prog. Polym. Sci., 24, 185 (1999).

b) H. Lang and B. Lühmann, Adv. Mater., 13, 1523 (2001).

c) A. Morikawa, M. Kakimoto, and Y. Imai, Macromolecules, 25, 3247 (1992).

4. K. Kim, M. Jikei, and M. Kakimoto, Polym. J., 34, 755 (2002),

5. K. Kim, M. Jikei, and M. Kakimoto, Polym. J., 34, 275 (2002).

6. L. J. Mathias and T. W. Carothers, J. Am. Chem. Soc., 113, 4043 (1991).

7. a) S. Rubinsztajn, J. Inorg. Organomet. Polym., 4, 61 (1994). b) S. Rubinsztajn and J. Stein, J. Inorg. Organomet. Polym., 5, 43 (1995).

8. a) J. F. Miravet and J. M. J. Fréchet, Macromolecules, 31, 3461 (1998).

b) C. Gong, J. F. Miravet, and J. M. J. Fréchet, J. Polym. Sci., Part A: Polym. Chem., 37, 3193 (1999). 
c) C. Gong, J. F. Miravet, and J. M. J. Fréchet, J. Polym. Sci., Part A: Polym. Chem., 38, 2970 (2000).

9. M. Oishi, M. Minakawa, I. Imae, and Y. Kawakami, Macromolecules, 35, 4938 (2002).

10. a) Q. Si, X. Wang, X. Fan, and S. Wang, J. Polym. Sci., Part A: Polym. Chem., 43, 1883 (2005).

b) Q. Si, X. Fan, Y. Liu, J. Kong, S. Wang, and W. Oiao, J. Polym.
Sci., Part A: Polym. Chem., 44, 3261 (2006).

11. a) C. Gao and D. Yan, Prog. Polym. Sci., 29, 183 (2004).

b) C. R. Yates and W. Hayes, Eur. Polym. J., 40, 1257 (2004).

c) M. Jikei and M. Kakimoto, Prog. Polym. Sci., 26, 1233 (2001).

12. K. Shintani, O. Doi, A. Mori, and Y. Kawakami, Polym. Bull., 37, 705 (1996).

13. D. Hölter, A. Burgath, and H. Frey, Acta Polym., 48, 30 (1997). 